ISSN 2078-6441. Вісник Львівського університету. Серія географічна. 2013. Випуск 42. С. 233-242. Visnyk of the Lviv University. Series Geography. 2013. Issue 42. P. 233-242.

911.3

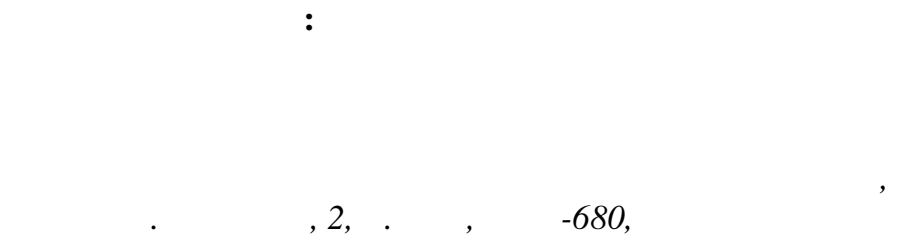

озглянуто сутність космічного туризму, передумови його виникнення т історію польотів туристів у космос. ро н лізов но ст н т виявлено перспективи розвитку космічного туризму. собливу ув гу приділено огляду м тері льно-технічної б зи космічного туризму (космопорти, космофлот, космічні готелі), попиту і цін н послуги для космічних туристів.

лючові слов : космічний туризм, космічний готель, космопорт, іжн родн космічн ст нція, омерційн космічн ст нція.

ояв пл тоспроможного попиту н космічні подорожі, відкриття спеці лізов них туристичних генцій, розробк тр нспортних з собів, призн чених винятково для перевезення туристів у космос - усе це свідчить про те, що космос нез б ром може перетворитися з об'єкт н укового дослідження н туристичну дестин цію.

огляду н суч сний дин мічний розвиток туризму, глоб ліз ційні процеси т появу іннов ційних н прямів розвитку змінюється тр диційне розуміння сутності туризму т його сприйняття. еоретики і пр ктики космічної спр ви ( . іолковський, . ондр тюк, . орольов, . нгель, . сядько, . иб льчич, . лушко, . $\mathrm{p}$ ун т ін.) зробили величезний внесок у розробку космічних п р тів т 3 поч ткув ли космічні прогр ми $\quad, \quad$ т інших кр їн. ьогодні м ємо щор з більше інформ ції щодо комерційного використ ння космосу, зокрем , розвитку космічного туризму, пит ння перспектив розвитку якого ктивно обговорюють н н укових конференціях. ед лі більше укр їнських н уковців цік виться цією проблем тикою ( . ильчук, . оліков, . кушенко, . омич). ому висвітлення ст ну т перспектив розвитку космічного туризму, передусім його м тері льно-технічної б зи, попиту т цін н космічний туризм, т кож технології обслуговув ння космічних туристів є кту льним.

ш мет - огляд передумов виникнення, н ліз суч сного ст ну т виявлення перспектив розвитку космічного туризму.

осмічним туризмом н зив ють політ бо серію польотів однієї чи кількох людей у космос (під космосом з звич й розуміють висоту, що перевищує 100 км н д рівнем моря - т к зв ну лінію рм н, умовну верхню межу тмосфери емлі) бо н н вколоземну орбіту, опл чену н комерційних з с д х з розв ж льною бо н уководослідною метою. юдей, які вируш ють у космос 3 свої кошти з розв ж льною метою, з звич й н зив ють космічними турист ми, одн к їхня офіційн н зв уч сники космічного польоту ( ), тому що н орбіті вони ст ють уч сник ми н укових експериментів, пізн ють, що т ке ризик космічного польоту, і пр цюють н рівні 3 екіп жем. ому космічний туризм ч сто н зив ють експедицієювідвідув нням, оскільки підготовк до польоту в туристів й екіп жу одн ков .

(C) линовськ ., 2013 
дея космічного туризму з'явил ся у твор х письменників-ф нт стів 3 довго до поч тку польотів людини в космос, одн к повноцінн ре ліз ція цієї ідеї почин ється лише сьогодні.

. ілтон (Barron Hilton) i . piкe (Kraft Ehricke) у 1967 р. опублікув ли кільк пр ць, присвячених космічному туризму, серед них - “ отелі в космосі” ("Hotels in Space”). ж ль, ця спроб привернути ув гу гром дськості до пит нь комерці ліз ції космосу не увінч л ся успіхом [8].

1984 p. у еликій рит нії вийшл перш серія публік цій . шфорд (David Ashford), присвячен створенню літ льного п р ту для туристичних польотів у космос.

дсон (Gary Hudson, комп нія Pacific American Launch Systems) 1985 р. предст вив гром дськості проект диз йну б г тор зового одноступінч стого повітрянокосмічного п р т "Phoеnix" (вертик льні зліт і пос дк ). ого ж року Pacific American Launch Systems p зом з туристичною комп нією Society Expeditions д ли ст рт проекту "Project Space Voyage" [8].

ік 1986 міг би ввійти в історію як рік, коли в космосі побув в перший турист: н борту космічного п р т “ елленжер”, який з зн в в рії під ч с зльоту, перебув л шкільн вчительк рісті коліфф. ісля цього вип дку уряд з боронив непрофесіон л м літ ти у космос. оді ж під ч с іжн родного конгресу строн втики (International Astronautical Congress) предст влено доповідь н тему “" мовірні економічні н слідки розвитку космічного туризму" (Potential Economic Implications of the Development of Space Tourism), як м л зн чний резон нс у н укових т ділових кол х [8].

іжн родному конгресі строн втики 1989 р. комп нія Shimizu Corporation, що пр цює в сфері будівництв, предст вил диз йн проекту орбіт льного готелю (Feasibility of Space Tourism - Cost Study for Space Tour).

1990 і 1991 pp. перші комерційні космон вти ( оехіро кіям 3 понії т елен рм н 3 еликої рит нії) здійснили польоти н р дянську орбіт льну ст нцію “ ир”, фін нсов ні корпор ціями TBS і “жуно” (спл чен сум з зн чен у по-різному (25, 28 бо 37 млн дол.) [8].

. шфорд (David Ashford) i . оллінс (Patrick Collins) у 1990 р. опублікув ли м тері л “ ш інструкція з космічних польотів: як ст ти космічним туристом протягом 20 років" (Your Spaceflight Manual: How you could be a tourist in space within 20 years).

рг ніз ція Japanese Rocket Society (JRS) 1993 р. оголосил про ст рт к мп нії з розвитку космічного туризму як виду підприємницької діяльності.

1997 р. в імеччині відкрився ерший міжн родний симпозіум з пит нь космічного туризму (First International Symposium on Space Tourism), орг нізов ний комп нією Space Tours Gmbh. дин із п ртнерів-спонсорів симпозіуму - комп нія DaimlerBenz Aerospace $\mathrm{GmbH}$ - поч в вл сну прогр му з вивчення пит нь космічного туризму.

ершого січня 1998 р. $з$ реєстров но першого японського космічного туропер тор Spacetopia Inc. оді ж у 3 снов но комп нію Space Adventures, діяльність якої поч л ся з орг ніз ції комерційних польотів н російських ре ктивних винищув ч х, т кож н літ ючій л бор торії “ л-76” для підготовки космон втів.

. pенсон (Richard Branson) у 1999 р. 3 снув в Virgin Galactic - першу в світі комп нію, мет якої - орг ніз ція суборбіт льних польотів для прив тних осіб. 
2000 р. оголошено ім’я першого “пл тного” гостя орбіт льної ст нції “ ир”. им ст в мерик нський бізнесмен іт лійського походження . іто (Dennis Tito), фін нсовий н літик, з сновник комп нії Wilshire Associates.

оч ток ери космічного туризму прип в н 28 квітня 2001 р., коли було з пущено космічний кор бель “ оюз -32” $з$ першим космічним туристом н борту . іто (до скл ду екіп жу т кож входили російські космон вти . ус 6 єв т . турин) [8]. есятиденн подорож коштув л 20 млн дол. (150 тис. дол. 3 кожний зі 128 витків н вколо емлі). омп нія MirCorp (як експлу тує орбіт льну ст нцію “ ир”) 24 серпня 2001 р. оголосил про укл дення з урядом осії, кетно-космічною корпор цією ім. . орольов “ нергія” і осійським ві ційно-космічним гентством (“ ос ві космос”) угоди, як передб ч л розробку і з пуск першої в світі прив тної космічної ст нції MiniStation-1.

2002 p. в уковському продемонстров но прототип космічного п р т “Cosmopolis XXI” для дост вки н орбіту космічних туристів, розроблений з уч стю дослідно-конструкторського бюро ясищев т мерик нської комп нії Space Adventures.

в дЦять п’ятого квітня 2002 р. бізнесмен з ․ ттлворт (Mark Shuttleworth) ст в другим в історії космічним туристом (до скл ду екіп жу т кож входили російський космон вт . ідзенко т іт лієць . ітторі) [8].

т строф ш тл “олумбія” (Columbia) із сімом член ми екіп жу н борту 1 лютого 2003 р. змусил гром дськість з дум тися про продовження розвитку космічного туризму як виду екстрем льного відпочинку т підприємницької діяльності.

пустелі ох ве 20 квітня комп нія Scaled Composites предст вил суборбіт льний космічний кор бель б г тор зового використ ння SpaceShipOne i літ к-носій White Knight. ев’ятн дцятого тр вня SpaceShipOne здійснив свій перший політ, 10 серпня вперше відбул ся реєстр ція космічного весілля (російський космон вт . л нченко перебув в н орбіті, н речен - . митрієв - н 17 грудня - SpaceShipOne уперше подол в звуковий 6 р'єр.

в дцять першого червня 2004 р. прив тний космічний кор бель б г тор зового використ ння SpaceShipOne здійснив перший суборбіт льний політ; 17 липня комп нія Constellation Services International (CSI) уперше предст вил прогр му орг ніз ції польотів до ісяця (Lunar Express Space Transportation System); 23 грудня у

підпис но з кон, що регл ментує пр в н проведення прив тних польотів людей у космос, згідно з яким гром дяни м ють повне пр во здійснюв ти польоти в космос н прив тних літ льних п р т х н свій стр х і ризик.

омп нії Scaled Composites i Virgin Group 27 липня 2005 р. оголосили про створення спільного підприємств Spaceship Company для розробки і з пуску літ льних п р тів SpaceShipTwo i White Knight2. ершого жовтня мерик нський учений i бізнесмен . лсен (Greg Olsen) ст в третім в історії космічним туристом (до скл ду екіп жу оюз $\quad-7$ т кож входили російський космон вт . ок рєв т мерик нський строн вт. к ртур) [8]. омп нія Virgin Galactic 17 жовтня поч л прийом 3 явок від 6 ж ючих ст ти космічними турист ми. ого ж року “ оскосмос” і Space Adventures підпис ли мемор ндум про н міри щодо підбору інвесторів т космон втівнепрофесіон лів для ре ліз ції проекту щодо польоту н вколо ісяця, з пропонов ного “ нергія”. ідповідно до мемор ндуму, Space Adventures отрим л ексклюзивні пр в з м ркетингу, “нергія” - пр во н технічне викон ння цього проекту. ольоти пл нув ли виконув ти н доопр цьов ному кор блі “ оюз”. 
2006 р. комп нія Prodea Systems розпоч л співпр цю з Space Adventures i едер льним космічним гентством осії, у р мк х якої пл нув ли створити цілий флот б г тор зових космічних кор блів для комерційних польотів. 18 вересня того ж року мерик нк ip нського походження . нс pi (Anousheh Ansari) ст л першим космічним туристом-жінкою, вон пройшл підготовку в осії т ьюстонському центрі NASA [8].

ьомого квітня 2007 p. мерик нський мільярдер угорського походження . імоні (Charles Simonyi) ст в п'ятим космічним туристом. ін бр в уч сть в експеримент х н 3 мовлення вропейського космічного гентств (дослідження впливу нев гомості н кров), т кож з вл сною прогр мою дослідження впливу р ді ції [8]. осії 23 червня 2008 р. розпоч то прод ж квитків н польоти кор бля SpaceShipTwo комп нії Virgin Galactic, його пров див предст вник Virgin Galactic у осії комп нія Elegant Resorts (в ртість квитк - близько 200 тис. дол.); 12 жовтня того ж року відбувся політ шостого космічного турист - мерик нського мільйонер . ерріот . ін був першим космічним туристом, який викон в н укові експерименти н 3 мовлення комерційних орг ніз цій (вирощув ння білкових крист лів) [8].

в дцять шостого березня 2009 р. відбувся політ сьомого космічного турист ( мерик нець . імоні полетів у космос удруге), 30 вересня - політ восьмого космічного турист i ліберте (з сновник і керівник к н дської комп нії Cirque du Soleil) [8].

2009 р. комерційні космічні польоти н іжн родну космічну ст нцію ( ) припинилися, оскільки припинили перевезення в нт жів н ш тл ми після к т строфи “ олумбії”. “ оскосмос” виявився єдиною орг ніз цією, зд тною з безпечити пост ч ння . в нт ження н “ оюзи” зросло, і це не д є змоги використовув ти їх ще і з туристичною метою. рім того, збільшився шт т до повної комплектності - шести осіб.

червні 2012 р. у рит нському королівському тов ристві ерон втики комп нія Excalibur Almaz провел презент цію і оголосил про свої пл ни щодо поч тку в 2015 р. туристичних космічних польотів н вколо ісяця.

о стосується суч сного ст ну розвитку інфр структури космічного туризму, то:

1) монополістом у сфері комерційних польотів н орбіту емлі є осійськ федер льн генція “ оскосмос", космічних туристів перевозять російськими космічними кор блями “ оюз” (доопр цьов ні модифік ції з вимог ми NASA - серія “ оюз-

”) н російський сегмент іжн родної космічної ст нції;

2) підготовку космічних туристів проводять у оряному містечку (м. елкове під осквою), т кож н невеликих літ к х, які симулюють нев гомість;

3) розробляють нові з соби розміщення для космічних туристів - орбіт льну омерційну космічну ст нцію (розробк комп нії “рбіт льні технології” т

“ нергія”), омерційну космічну ст нцію Bigelow (розробк прив тної комп нії BigelowAerospace) т космічні готелі;

4) $є$ прив тні фін нсов ні проекти, спрямов ні н розробку вл сних р кет-носіїв, суборбіт льних т орбіт льних космічних кор блів, з явлен мет яких - зробити польоти в космос доступними з порівняно невелику пл ту (очікують польоти н т ких туристичних п р т х, як LYNX комп нії XCOR, ерост тно-р кетних п р т х типу ARCASPACE т р кетних п р т х типу Copenhagen Suborbitals);

5) у г лузі орбіт льного туризму н йбільш суттєві т ч стково впров джені проекти м ють комп нії Bigelow Aerospace, SpaceX, Excalibur Almaz, Orbital Sciences. 
ля розміщення космічних туристів пропонують т кі з соби розміщення: іжн родну космічну ст нцію (єдиний сьогодні з сіб розміщення) т космічні готелі (перебув ють н ст дії проектів).

іжн родн космічн ст нція - пілотов н орбіт льн ст нція, яку використовують як $б$ г тоцільовий космічний дослідницький комплекс. е спільний міжн родний проект, у якому беруть уч сть 15 кр їн ( ельгія, р зилія, нія, сп нія, т лія, н д , ідерл нди, імеччин, орвегія, осія, , р нція, вейц рія, веція, понія). пр вління 3 безпечують: російським сегментом - 3 ентру упр вління космічними польот ми в орольово, мерик нським сегментом - 3 ентру упр вління польот ми у ьюстоні (між центр ми відбув ється щоденний обмін інформ цією).

$\epsilon$ н йбільш відвідув ним орбіт льним космічним комплексом в історії космон втики (н 17 січня 2012 р. кількість відвідув нь ст новил 328; якщо не р хув ти повторних візитів, то н ст нції побув ло 204 космон вти; для порівняння - н ст нції “ ир” $з$ всю історію іiі існув ння кількість відвідув нь ст новить 137, побув ло 104 космон вти). ідст нь від емлі до м йже н половину менш, ніж відст нь від оскви до нкт- етербург - 350-370 км [1]. т ном н поч ток 2013 p.

відвід ли вісім космічних туристів, кожний з яких з пл тив від 20 до 30 млн дол. [9].

осмічний готель - орбіт льн ст нція, призн чен для прожив ння космічних туристів і обслуги індустрії космічного туризму. роекти космічних готелів розробляють прив тні комп нії Bigelow Aerospace т “ рбіт льні технологіі”. пуски готових проектів пл нують у 2015-2016 pp. [7].

прикл д, російськ комп нія “ рбіт льні технології” т “нергія” розробляють проект омерційної космічної ст нції ( ) для орбіт льного космічного туризму й інших космічних місій. орівняно з , як не призн чен для комфортного прожив ння туристів, космічний готель з безпечув тиме дост тній рівень комфорту.

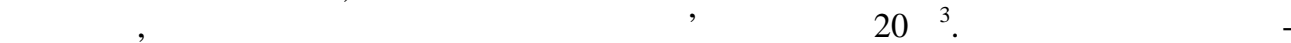
му готелі буде чотири к юти і в ньому зможуть одноч сно перебув ти до семи осіб. роектом передб чен можливість стикув ння російських, європейських, мерик нських т кит йських космічних кор блів. пл нують використовув ти не тільки для туризму, й як пл тформу для н укових досліджень. лієнти готелю зможуть обр ти тип ліжк (вертик льний чи горизонт льний) т користув тися душем. ередб ч ють, що п’ять днів перебув ння в готелі коштув тиме 100 тис. фунтів стерлінгів, всі витр ти н космотур з г лом ст новитимуть 500 тис. фунтів стерлінгів [5].

2007 p. ісп нськ комп нія Galactic Suite презентув л проект першого космічного готелю Galactic Suite Space Resort (виведення н орбіту пл нув ли у 2012 р.) [14]. голошен в ртість триденного перебув ння - 3 млн дол. озробники очікув ли, що цей готель ст не першим у н йбільшій мережі космічних готелів Galactic Suite Limited (GSL). езв ж ючи н високу в ртість прожив ння, 3 січня 2008 р. готель уже отрим в 38 з мовлень від туристів (перев жно із ). юкс м тиме три сп льні з вікн ми і сяг тиме 7 м у довжину т 4 м у висоту. тіни м тимуть спеці льні виступи, гостям вид в тимуть спеці льні костюми з липучк ми, щоб можн було з кріпитися для сну бо прийм ння їжі й уникнути ст ну нев гомості. роект т кож передб ч $є$ перший космічнй і космодром н острові у рибському морі [15].

ст дії проекту перебув є омерційн космічн ст нція Bigelow - прив тний орбіт льний космічний комплекс, розроблений BigelowAerospace. т нція скл д тиметься 3 двох н дувних елементів, стикув льного вузл , сонячних 6 т рей і пристиков них пілотов них к псул. иведення н орбіту призн чене н кінець 2015 р. роектом 
передб чен можливість стикув ння кор блів різних типів. л нують, що цим космічним готелем користув тимуться прив тні особи, професійні екіп жі, т кож корпор тивні дослідники. ідбир тиме к ндид тури, можливо, комп нія Space Adventures [6].

омп нія Bigelow Aerospace т кож розробляе ідею космічного готелю "Nautilus", який пл нув ли вивести н орбіту до 2010 р., одн к ф ктично досі виведено лише дв п р ти, які демонструють можливості комп нії. ля ре ліз ції проекту розробники використ ли з кинутий проект н дувної космічної ст нції “Nautilus", розроблений NASA. одуль зд тний з безпечити $330 \mathrm{~m}^{3}$ корисного простору, призн ченого для космічних туристів бо дослідників [13]. 2004 р. 3 явлен в ртість перебув ння в м йбутньому космічному готелі ст новил 14,5 млн дол. 3 чотири тижні, у 2010 р. прозвуч л цифр 1 млн дол. 3 добу. езв ж ючи н те, що 2010 р. готель не відкрили, комп нія розпоч л н бір строн втів, які обслуговув тимуть космічний готель і прив тну орбіт льну ст нцію. рийом перших гостей н мічено н 2015 р.

тосовно розвитку космофлоту з зн чимо т ке.

1. ля перевезень у космос використовують орбіт льні літ ки т повітрянокосмічні літ ки - крил ті літ льні п р ти, які виходять, бо їх виводять н орбіту штучного супутник емлі вертик льним бо горизонт льним ст ртом і поверт ються після викон ння з вд нь, роблячи горизонт льну пос дку н еродром. они поєднують у собі х р ктеристики як літ к, т к і космічного кор бля. лежно від способу виходу н орбіту їх поділяють н космопл ни т космолети [10].

2. осмопл ни т космолети можуть т кож бути суборбіт льними - призн ченими лише для перевищення межі космосу у 100 км.

3. осмопл ни виводять н орбіту не лише з допомогою вл сних двигунів, й 3 допомогою р кети-носія.

н р зі трив є проект з польот ми н орбіту експеримент льного космопл н Boeing X-37. озробляють т кі проекти: в ндії космопл н RLV/AVATAR, у ит ї-“ еньлун”, в кр їні-“ ур ”т ін. [10].

4. поч тку ст. поч ли розвив ти декільк проектів прив тних суборбіт льних космопл нів. 2004 р. здійснено польоти першого з т ких п р тів SpaceShipOne комп ніï Virgin Galactic. ступними очікують прив тні суборбіт льні космопл ни XCOR LYNX [10].

5. осмолети виходять н орбіту з допомогою вл сних двигунів у р зі вертик льного бо горизонт льного ст рту, одн к через скл дність конструкційних технологій жоден $з$ проектів поки що не ре лізов но. еред т ких проектів у осії -

у - VentureStar i NASP, у еликій рит нії-HOTOL [10].

грудні 2009 р. комп нія Virgin Galactic предст вил р кетопл н SpaceShipTwo, який бере н борт двох пілотів і шість п с жирів. поч тку комп нія зробил 3 мовлення н дв літ ки-носії WhiteKnightTwo і п’ять р кетопл нів SpaceShipTwo. ерші випробув ння SpaceShipTwo без відстикув ння від WhiteKnightTwo успішно відбулися в березні 2010 р., 3 повним екіп жем н борту - у липні 2010 р. [10].

осія у 2010 р. розпоч л будівництво нового орбіт льного пілотов ного космічного кор бля “ оюз ”, призн ченого і для космічного туризму. кіп ж кор бля скл д ється з двох-трьох осіб. ерший політ до “ оюзу ”відбувся 2012 р.

півробітники “нергія” створюють принципово новий легкий космоліт б г тор зового використ ння “ усь”. ередб ч ють, що він досяг тиме 3 добу, тоді як нині стикув ння відбув ється в “дводобовому режимі”, вибр ному свого ч су не тільки $з$ лістичними, й з медичними пок зник ми. оч ток випробув нь 3 пл нов но н 2015 р. пуски споч тку робитимуть з космодрому “" йконур” ( 3 хст н), 
потім з космодрому “ хідний” ( мурськ обл.), який передб ч ють зробити б зовим для “ усі”. “нергія” з явил, що “ усь” буде втричі економічнішою, ніж н лог NASA. л нують створення кількох модифік цій цього кор бля, які призн чені для польотів н земну і н вколомісячну орбіту, ремонту космічних п $\mathrm{p}$ тів, т кож для виведення з орбіти великих фр гментів космічного сміття. овий кор бель використовув тимуть і для космічного туризму. зов модель кор бля зможе взяти н борт шість осіб і не менше 500 кг корисного в нт жу з втономного існув ння до п'яти діб. ор бель розр хов ний н б г тор зове використ ння (до 10 польотів у космос) [4].

2005 р. комп нія Virgin Galactic взял уч сть у робот х зі спорудження першого прив тного космопорту емлі Spaceport America н території шт ту ью- ексико у . осмопорт м $є$ площу 11 тис. ${ }^{2}$, н яких розт шов но нг р, розр хов ний н дв космічні кор блі кл су White Knight Тwo (літ к-носій) і дв кор блі кл су SpaceShipTwo (космічний ш тл), приміщення для дміністр ції т космічних туристів [11].

роектув льники $90 \%$ приміщень і споруд космопорту розмістили під землею, будівлю п с жирського термін л зробили схожою н “ исячолітнього сокол " культового фільму 1970-х років “ оряні війни”. л нов пропускн спроможність космопорту - чотири польоти в день. ртість проекту - 225 млн дол. $\quad$ грудні 2008 р. космодром отрим в ліцензію н прийом т відпр вку прив тних космічних кор блів, призн чених для суборбіт льних польотів. омп нія Virgin Galactic є першим офіційним користув чем космопорту “ мерик”, вон вже здійснил п’ять суборбіт льних 3 пусків з цього космодрому [6]. ипробовув льний з пуск р кети STIG-A, створеної для потреб космічного туризму (м ксим льн висот підйому р кети перевищил 80 км), здійснено 28 грудня 2012 р. же сьогодні є черг з 400 осіб, які з пл тили по 200 тис. дол. 3 пр во здійснити суборбіт льний політ у р мк х проекту Virgin Galactic [11].

перспективі прив тні земні космопорти побудують у шингтоні, окіо, іднеї, ондоні, екіні, уб ї, ейпт уні, р зилі, оскві, лм ти, ью- елі, інг пурі т н б зі космодрому “ ірун” у веції, для того, щоб пов’яз ти земну кулю мережею високошвидкісних перельотів.

ершим космопортом н орбіті емлі вчені припуск ють зробити , термін експлу т ції якої з вершується в 2020 р., ресурс експлу т ції ст новитиме ще не менше десяти років. - імовірний ст ртовий м йд нчик для експедиції н рс, яку прогнозують н 2030-ті роки, т кож для інших міжпл нетних експедицій м йбутнього.

ез б ром поряд із тр диційними туропер тор ми може з'явитися безліч космічних тур генцій. йближчі до ре ліз ції доступних для м сового космічного туризму польотів прив тні комп нії Virgin Galactic і Space Adventures. роект суборбіт льних (100-110 км від емлі) польотів розробляе т кож вропейський ерокосмічний i оборонний концерн (European Aeronautic Defence and Space Company (EADS)).

йвідомішою комп нією, як пр цює в цій г лузі, $є$ Virgin Galactic. он проводить випробув ння спеці льного тр нспорту для туристів SpaceShipTwo. ртість путівки в космос н т кому кор блі ст новитиме близько 200 тис. дол. 3 двогодинний політ із короткоч сним підйомом до висоти $110 \mathrm{KM.} \mathrm{кор} \mathrm{блі} \mathrm{у} \mathrm{космос} \mathrm{одноч} \mathrm{сно}$ зможуть полетіти чотири туристи і дв члени екіп жу. уристи зможуть випробув ти перев нт ження під ч с зльоту т пос дки, т кож кільк хвилин нев гомості. опит н послугу передб ч ють великий - квитки н перші рейси вже розкуплені, н решту утворил ся черг в десятки тисяч осіб. омп нія пл нує відпр вляти по три-чотири p кети з турист ми в день. 250 людей, які першими придб ли путівки в космос, - 
11 росіян. р мк х світового конкурсу “ олети хлопцем - повернися героєм!” з пон д 20 тис. претендентів відібр но двох укр їнців. оліт у Virgin Galactic можн з мовити в 33 кр їн х світу. омп нія Virgin Galactic обіцяе допуск ти до суборбіт льних польотів усіх 6 ж ючих після невеликого медичного огляду т триденної підготовки н космодромі. зн чимо, що для орбіт льного (340-360 км від емлі) польоту н потрібно н б г то ретельніший відбір і не менш ніж шестимісячн підготовк ; т кі пр вил були узгоджені кр їн ми-уч сницями у 2002 р. в “ ринцип х, що стосуються процесів т критеріїв відбору, призн чення, підготовки і сертифік ції членів основних екіп жів і експедицій відвідув ння".

омп нія-конкурент Space Adventures м є н мір здійснюв ти не тільки суборбіт льні польоти, й обліт ісяця (спільний проект з “нергія”). он будує космопорти в і інг пурі.

мерик нськ комп нія Armadillo Aerospace, як співпр цює зі Space Adventures, оголосил 2010 р. про н йменшу в ртість польотів - 102 тис. дол. 315 хв у космосі. еред польотом кожен космічний турист пройде б г тоденну підготовку. рубіжні експерти вв ж ють, що ринок суборбіт льних польотів д сть змогу знизити в ртість квитК в космос у 2014 р. до 50-100 тис. дол.

тимулом для з родження і розвитку космічного туризму з боку світової гром дськості був попит - спожив чі, готові з пл тити гроші з яскр ву пригоду (в ртість туру н орбіту ст новить від 20 до 40 млн дол., в ртість виходу у відкритий космос 15 млн дол.) [2]. рг ніз ція польотів у космос н комерційних з с д х - це повноцінний $\mathrm{i}$, що н йголовніше, рент бельний бізнес. рубіжні т вітчизняні інвестори сходяться н думці, що стимулів для розвитку космічного туризму $б$ г то, серед них н зив ють т кі: н явність попиту, можливість втілення б г тьох ідей, можливість 3 робити н “невичерпних космічних ресурс х", можливість поєдн ння бг тьох земних видів бізнесу (почин ючи 3 м ркетингу, моди, рхітектури, технологій і з кінчуючи виготовленням сувенірів т н д нням оригін льних послуг для н йбільш ексцентричних клієнтів).

стково космічний туризм можн порівняти із “земним”: основний потік клієнтів ст новить середній кл с. дн к н ринку є місце для послуг кл су “люкс" - дорогий ексклюзив, який теж користується попитом. езв ж ючи н всі перев ги і можливості сервісів для космічних туристів, популярність і попит н цей вид бізнесу б г то в чому з лежить від в ртості путівки. цьому вип дку споживчий ринок послуг космічного туризму можн розділити н дві групи: перш - це ринок 3 можних клієнтів, готових з пл тити з подорож у космос не один мільйон дол рів, друг груп - ринок менш з безпечених клієнтів, для яких можуть бути доступними суборбіт льні польоти.

ьогодні в кол х $б$ нкірів і підприємців ведуть дискусії щодо кредитув ння космічних подорожей. е один в рі нт популяриз ції польотів, з пропонов ний строн втом і головою ShareSpace Foundation . лдрином (Buzz Aldrin), - космічн лотерея, коли ш нс вигр ти путівку з'являється в кожного. рім того, космічний турист зможе прод ти свої ексклюзивні фотогр фії т інші відеом тері ли, зняті ним під ч с космотуру, і ч стково окупити свою подорож (з пр вил ми н д ння послуг космічного туризму всі пр в н використ ння т ких м тері лів н леж ть винятково туристу).

генції, які пр цюють у сфері космічного туризму, пропонують т кож льтерн тивні, дешевші в рі нти послуг: 
- політ н літ ку по п р болічній тр єкторії з можливістю відчути нев гомість (у це коштує близько 3,5 тис. дол.);

- політ н великій висоті н літ ку і -24 бо і -31 з можливістю поб чити емлю з висоти 26 км $з 24$ тис. дол.;

- як перше озн йомлення з космічною г луззю можн здійснити груповий бо індивіду льний тур н йконур;

- н йдешевший в рі нт побув ти в космосі з пропонув в прогр міст із нкTетербург . нтонов (у 2010-2011 pp. 333 руб. він пропонув в відпр вити в космос фотогр фію людини бо логотип фірми площею $\left.1 \mathrm{~cm}^{2}\right)$.

тже, з 12 років від поч тку комерційних польотів у космос відбулося вісім ст ртів. кі темпи розвитку індустрії космічного туризму д ють підст ви сподів тися, що в нед лекому м йбутньому туристичні опер тори зможуть 3 пропонув ти клієнт м космічний готель 3 вікн ми н встр лію бо под лі від орбіти з хоронення космічного сміття т екскурсії у відкритому космічному просторі. од льші ж н укові дослідження можуть стосув тися м ркетингових спектів розробки іннов ційного космічного турпродукту, особливостей орг ніз ції обслуговув ння космічних туристів, специфіки орг ніз ції підприємницької діяльності в г лузі комерційних космічних польотів, економічних т екологічних н слідків розвитку космічного туризму.

1. 3 ров . осмос:[ лектронний ресурс]. - ежим доступу: http://tonkosti.ru/ осмос.

2. 3 ров . уры в осмос : [ лектронний ресурс]. - ежим доступу: http://tonkosti.ru/ уры_в_ осмос.

3. мерик (космопорт) : [ лектронний ресурс]. - ежим доступу: http://ru.wikipedia.org.

4. оенные одобрили проект нового российскогокосмолет “усь”: [ лектронний pecypc]. - ежим доступу: http://www.newsru.com/russia/18jun2010/rus.html.

5. оммерческ я космическ я ст нция : [ лектронний ресурс]. - ежим доступу: http://ru.wikipedia.org.

6. оммерческ я космическ я ст нция игелоу : [ лектронний ресурс]. - ежим доступу: http://ru.wikipedia.org/wiki/ оммерческ я_космическ я_ст нция.

7. осмический отель: [ лектронний ресурс]. - ежим доступу: http://ru.wikipedia.org/ wiki/ осмический_отель.

8. осмический туризм : [ лектронний ресурс]. - ежим доступу: http://ru.wikipedia.org/ wiki/ осмический_туризм.

9. еждун родн я космическ я ст нция : [ лектронний ресурс]. - ежим доступу: http://ru.wikipedia.org/wiki/ еждун родн я_космическ я_ст нция.

10. рбит льный с молет : [ лектронний ресурс]. - ежим доступу: http://ru.wikipedia.org/ wiki/ рбит льный_с молет.

11. ткрылся первый ч стный космопорт - Spaceport America: [ лектронний ресурс]. - ежим доступу: http://www.novate.ru/blogs/261011/19158/

12. ерв я космическ я св дьб едв не стоил космон вту к рьеры: [ лектронний pecypc]. - ежим доступу: http://ria.ru/society/20080810/150249971.html. 
13. едоров . осмический отель Nautilus : [ лектронний ресурс]. - ежим доступу: http://www.mobiledevice.ru/Nautilus-NASA-Bigelow-Aerospace-modul-kosmicheskiiturizm-otel.aspx.

14. Galactic Suite Space Resort:[ лектронний ресурс]. - ежим доступу: http://galacticsuitespaceresort.com.

15. Unusual Hotels: Galactic Suite Space Resort in Barcelona, Spain: [ лектронний pecypc]. - ежим доступу: http://layyourheadhere.com/unusual-hotels-galactic-suitespace-resort-in-barcelona-spain.

\author{
m ття: н дійшл до ред кції 08.08.2013 \\ доопр иьов н 03.09 .2013 \\ прийнят до друку 10.10.2013
}

\title{
SPACE TOURISM: STATE AND WAYS OF DEVELOPMENT
}

\section{Oksana Malynovska}

\author{
Taras Shevchenko National University of Kyiv, \\ Glushkova Ave., 2, Kyiv-GSP-608, Ukraine
}

There were looked out the essence of the space tourism, the conditions of its beginning and the history of flights of the space tourists. There were analyzed the state and ways of development of the space tourism. The main attention was devoted to the facilities of the space tourism (space ports, space aviation and space hotels), demand and prices for the services for space tourists.

Key words: Space tourism, Space hotel, Spaceport, International Space Station, Commercial Space Station.

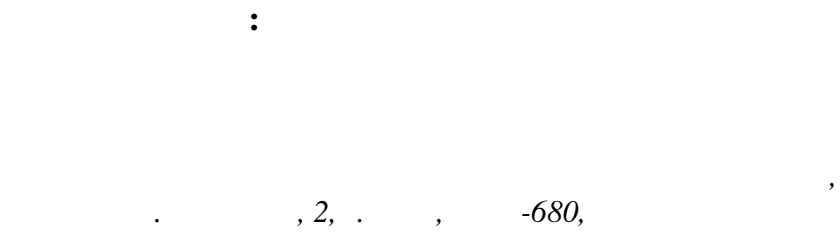

ссмотрено сущность космического туризм , условия его возникновения и историю полетов туристов в космос. ро н лизиров но состояние и выявлено перспективы р звития космического туризм . собенное вним ние уделено обзору м тери льно-технической б зы космического туризм (космопорты, космофлот, космические отели), спрос и цен н услуги для космических туристов.

лючевые слов : космический туризм, космический отель, космопорт, еждун род я космическ я ст нция, оммерческ я космическ я ст нция. 